\title{
Motivational Landscape and Evolving Identity of a Route-Based Religious Tourism Space: A Case of Camino de Santiago
}

\author{
Hany Kim ${ }^{1}$, Semih Yilmaz ${ }^{2}$ and Soyoun Ahn ${ }^{3, *}$ \\ 1 Department of Tourism and Convention, Pusan National University, Busan 46241, Korea \\ 2 Department of Hospitality, Recreation and Tourism, California State University, East Bay, Hayward, \\ CA 94542, USA \\ 3 Department of Hospitality and Tourism Management, Sejong University, Seoul 05006, Korea \\ * Correspondence: syahn0205@naver.com
}

Received: 9 May 2019; Accepted: 25 June 2019; Published: 27 June 2019

\begin{abstract}
Religious destinations today are visited by a large number of tourists, whose travel motives may vary from purely religious to purely secular. Diverse motives and on-site experiences are, in turn, causing a shift in the identity perception of these destinations. However, research is still limited regarding the dynamic relationship between travelers' motivation and the perceived identity of a religious space. Using a theoretical-thematic analysis, this study analyzes the online written accounts of visitors to Camino de Santiago (a route-based pilgrimage site) to understand (i) the motivational and experiential differences among religious versus non-religious travelers, and (ii) the perceived identity of Camino with respect to Smith's "pilgrimage-tourism continuum". Despite the increase in secular motives, the majority of travelers showed some form of spiritual connection with Camino. Concurrent with the contemporary shifts in the idea of "religion", Camino continues to be a religious place driven by inner goals, albeit in a more personal, interpretive, and "spiritual" way.
\end{abstract}

Keywords: religious tourism; route-based tourism; pilgrimage; destination identity; motivation; push-pull; Camino de Santiago

\section{Introduction}

The rise of living standards, demand for novelty, and competition among tourism industries have led to the diversification of tourist typologies, products, and activities [1]. Through diversification strategies, niche types of tourism have continuously emerged, breaking away from the mass tourism market; such as ecotourism [2-4], sport tourism [5,6], dark tourism [7-9], voluntourism [10,11], and many more (youth tourism, geotourism, genealogy tourism, tribal tourism, virtual tourism, adventure tourism, route-based tourism, and so on) [12]. While current research is heavily focused on identifying or conceptualizing new forms of tourism [13-16], it has somewhat neglected the repercussions on the so-called older forms of tourism, such as those that are religiously motivated. Nevertheless, the increasing pressure to diversify tourism has brought some traditional locations of religious (as well as cultural) importance back to the front stage. This has been possible through the reinterpretation and reinvention by tourists, tourism authorities, and the industry. This study specifically focuses on an iconic destination of religious interest, Camino de Santiago (Camino in short), whose identity as a destination may be as dynamic as the motives of its visitors. Camino has been considered fertile land for pilgrimage and religious tourism research owing to the structural, historical, cultural, and motivational diversity that surrounds it [17-24]. It is also seen as a sustainable destination where the flow of tourists and services embody environmental consciousness [23]. From an economic 
standpoint, however, a sustainable destination should also justify its investments and resource allocation by providing superior benefits to the host communities and safeguarding its assets to maintain its attractiveness for profitable markets [25-27]. Elaborating on sustainable competitive advantage, Ritchie \& Crouch [25] emphasize the importance of understanding the characteristics of visitors or consumers, as well as the local culture among the various constituents of the macro- and microenvironments. While the continued appraisal of the motivations of visitors is crucial for the economic sustainability of Camino, the implications of the motivational landscape also pertain to the social sustainability of the route. Traditionally starting in France and spanning across Spain, additional connecting routes for Camino have continuously been promoted throughout Europe. Intercultural exchange has long been at the core of Camino, rendering its pilgrims more than mere visitors $[17,22]$. In other words, Camino can be considered a destination where the majority of its locals are perpetually transient. Hence, the motivational make-up of its travelers is not external or tangential to the continued well-being of its locals, but an integral part of it $[25,27,28]$.

Religiously motivated tourism (such as pilgrimages or other forms of faith-based travel) is considered as one of the oldest forms of tourism [29-32]. World Tourism Organization (UNWTO) estimates that over 300 million tourists travel for religious purposes every year, generating approximately 600 million inbound and outbound visits annually [33]. These travelers include followers of major world religions, such as Christianity, Islam, and Hinduism, as well as people of other faiths [34]. Even though pilgrimage destinations continue to attract a large number of visitors throughout the world, as a subject area, it is still a growing field, particularly in terms of how the contemporary motivationscape surrounding a pilgrimage destination interacts with its perceived identity on a personal level [19,20,35-39]. An anthropologically long-contested area of pilgrimage [40-42] is even more equivocal when its motivational dimension is considered from a tourism perspective, so much so that it becomes harder to distinguish a pilgrim from a tourist [43-46]. This also holds true for the route-based destination of Camino de Santiago [22,23,47,48]. Unlike medieval pilgrims, visitors of pilgrimage sites in modern times do not always have a purely religious or spiritual motive [19]. Santos [47] reports that even though the sharp decline of the officially recorded number of visitors with purely religious motives (from over $80 \%$ by the end of 1980 s to around $50 \%$ in the $1990 \mathrm{~s}$ ) might be questionable as a result of biases in recording, various sources point to the fact that the fraction of those with only religious motivation to visit Camino is decreasing. For instance, a 2017 survey of Camino travelers found that 43 percent indicated a primarily religious motive, while 52 percent reported to have a "religious and other" motive, including cultural and health purposes [49]. This trend is not unique to Camino, as many religious sites around the world are increasingly visited without a distinct religious motive [35]. However, research has been limited in terms of how the experience of religious places varies in relation to the religiosity of the travel motivation, and how the diversity of such experiences, in turn, plays a role in the identity perception of these religious places, be they shrines or cultural tourism attractions. Recently, there has been a growing interest in the motivational make-up surrounding Camino [19], as well as the perceived identity of the sites involved [50,51]. However, concerning the interaction between identities and visitors' motivations, only the historic city of Santiago de Compostela has so far been investigated [51], not the route as a whole. In terms of the motivations for the route, Amaro et al. [19] have very recently analyzed the motives of Camino travelers in relation to other sociodemographic factors. While these authors criticized the lack of inquiry in previous studies regarding the "real" motivations behind the journey, their quantitative analysis relied on motivational items derived from previous research. To the best of the authors' knowledge, none of the previous studies examined the variations in motives with respect to the repercussions on the perceived identity of Camino. Therefore, it remains necessary to explore and identify the dynamics between motivation and destination identity of Camino. As the boundaries between seemingly contrasting motivations continue to blur, Camino's perceived identity might be changing for its old and new adherents. 
While the official, ceremonial, or local identities of a place may depend on many different factors and parties, this study is concerned with the identity of a place as a destination (destination identity) as perceived by its visitors. According to Urry and Larsen [1], destination identity is overwhelmingly influenced by how travelers perceive a destination based on their knowledge, experience, and travel reasons [1]. Even though this infamous "tourist gaze" account is perhaps outdated in its assignment of a unidimensionally destructive role to tourists [52-55], or in neglect of the psychological aspects of the tourist experience [56], tourists' role in the identity-making of any destination is difficult to deny. Furthermore, the role of tourists in the identity of a destination such as Camino may be even more pivotal because of its route-based nature. Unlike many specific spots of cultural or natural value along Camino (including the end point, Santiago de Compostela) that are essential elements of Camino's constitution, Camino as the route or The Way may not be deducible from these elements or their values alone [57]. Camino is the embodiment of pilgrimage as an activity. Without pilgrims, Camino would have not existed even though all the scenery, churches, and towns might have. This kinetic, active quality of Camino necessitates "actors" for its definition, making its travelers-be they pilgrims, tourists, or the ones in between-its locals and the primary constructors of its identity, if not the only ones. In this sense, the goal of this study was to understand the identity of a popular, religious route-based destination from the perspective of present-day travelers, who might be categorized differently in terms of their travel motivations. Hence, understanding the nature of the travel motivations as well as the actual experience of Camino in visitors' own terms was central to this goal. A theory-based thematic analysis was the main methodology of this research, which utilized insights from two conceptual frameworks-the push-pull framework of motivation, and Smith's [58] pilgrimage-tourism continuumto assist the data analysis and interpretation processes. While the push and pull framework provided a broad guide to understanding the variation in motivations and experiences, Smith's [58] previously established typology of tourism helped guide the interpretation of experiences and identity-making of Camino $[59,60]$ by its visitors.

\section{Background}

\subsection{Pilgrimage and Pilgrimage Tourism}

Pilgrimage is a common phenomenon among all major religions, such as Buddhism, Christianity, Hinduism, Islam, and Judaism [31,61,62]. Barber [63] defined pilgrimage as "a journey resulting from religious causes, externally to a holy site and internally for spiritual purposes and internal understanding" (p. 1). The understanding that pilgrimage involves both a spiritual and a physical journey or movement seems to be shared by researchers $[58,64,65]$. Today, pilgrimage sites are visited by the religious and less or non-religious alike, and the wide spectrum of travel motives renders these sites an important resource for tourism [19]. However, few researchers have attempted to identify the differences in motivations and experiences of pilgrimage site visitors [17,19], or how the meaning of these sites [50] may differ based on motivations and experiences. Scholars and historians have only recognized a superficial relationship between tourists and pilgrims for several decades [58], and research regarding religious tourists as a market segment is still lacking $[19,58,66,67]$. A number of scholars have conceptualized the relationship between tourism and pilgrimage as a dichotomy $[58,68]$. Most notably, Smith [58] identified tourism and pilgrimage as opposite end points on a continuum - the pilgrim-tourist path (Figure 1). Coleman [69] argues that there is a clear difference between tourism and pilgrimage, such that tourism primarily constitutes a leisure activity while pilgrimage is more of a sacred journey. However, understanding the historicity of the link between tourism and pilgrimage might be necessary for a better understanding of religious tourism.

The linkage of tourism and pilgrimage or how pilgrimage as a concept can be pivotal to understanding the nature of tourism experience is evident in tourism research. MacCannell [70] was among the first to suggest the central role authenticity plays in tourism motivations and experience. He claimed that tourists can be perceived as the modern pilgrims searching for authenticity in a 
modern secular world [71]. Similarly, Cohen [72] proposed a continuum to distinguish between five tourist typologies depending on the mode of tourist experience and motivation. Within this continuum, existential tourists were suggested to seek the quest for meaning and authenticity that characterizes pilgrimage. Collins-Kreiner and Kliot [61] also alluded to the "sacredness" of the tourists' journey through which one escapes from everyday life. Turner \& Tuner [40] refer to the tourist and the pilgrim as follows: "a tourist is half a pilgrim, if a pilgrim is half a tourist" (p. 20). For Turner \& Turner [40], a pilgrimage can be seen to be organized and to consume the same resources as secular tourism if viewed from the perspective of the tourism industry. This notion is shared by several others $[17,58,72]$ in the argument that it is increasingly difficult to distinguish pilgrimage from tourism in modern society or to use the words "pilgrim" and "tourist" in a mutually exclusive manner, as their cultural meanings are continually reconstructed and intertwined.

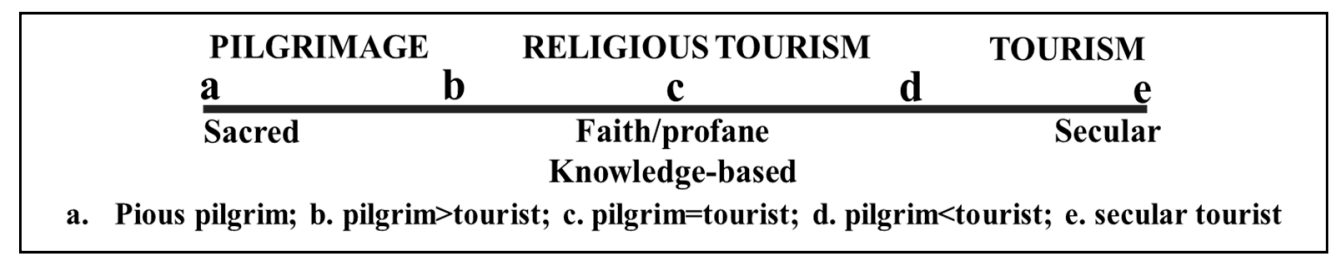

Figure 1. The pilgrim-tourism path after Smith [58].

Within this blurry relationship between pilgrimage and tourism, religious tourism may be associated with the individual quest for shrines and locales, where visitors seek to experience a sense of identity with sites of historical and cultural meaning [73]. Rinschede [31] proposed that religious tourism is a type of tourism where participants are motivated, either in part or exclusively, for religious reasons; although in current times, religious tourism might be drawing closer to tourism types that might be less or non-religious, such as heritage or leisure-based tourism. On Smith's [58] pilgrimage-tourism continuum, religious tourism lies in the center with a balance, arguably more representative of the contemporary religious experience. Even though Smith's continuum or previous literature does not offer clear distinctions between pilgrimage and tourism, the common argument point is the increasing complexity of the relationship between these phenomena.

\subsection{Camino de Santiago: A Millennium-Old Pilgrimage Route}

Together with Santiago de Compostela, Camino de Santiago is one of the three major pilgrim sites for Christians, besides Rome and Jerusalem. Spanish for "road to St. James", Camino de Santiago is the pilgrimage route that leads to the historic town of Santiago de Compostela. Camino became a pilgrimage center in the 10th Century after St. James' (one of the twelve apostles of Jesus) tomb was believed to be found in $928 \mathrm{AD}$. After having been walked on by bishops and the establishment of the Jubilee by Pope, the number of pilgrims on Camino increased. Camino has nine different main routes or ways, and multiple different starting points throughout Europe to start the pilgrimage "walk". Traditionally, the walk starts in Saint-Jean-Pied-de-Port and finishes in Santiago de Compostela over a distance of $780 \mathrm{~km}$. By the 13th century, this long route was believed to be walked by 500,000 pilgrims a year [23]. These glory days of medieval pilgrimage faded over time. However, in the last three decades, Santiago has been experiencing a revival with an increasing number of pilgrims, as indicated by the trend in certificates of completion issued every year (Table 1). Certificates of completion —or "Compostelas" - are given to the pilgrims who, by walking or cycling, collect dated stamps in a special passport from designated churches, cafes, and inns along the pilgrimage route. The cathedral authorities also record the motivation of travel from the certificate recipients, as well as other information such as occupation, mode of travel, country of origin, and so on.

The figures in Table 1 refer to "Compostelas" officially issued by the Pilgrim's Reception Office under the Cathedral of Santiago de Compostela [49]. Compostela is considered to be evidence of completing the pilgrimage and is given regardless of the recipient's religious background. 
Table 1. Number of Compostelas issued.

\begin{tabular}{ccccccccccc}
\hline Year & $\mathbf{1 9 8 6}$ & $\mathbf{1 9 9 6}$ & $\mathbf{1 9 9 9 *}$ & $\mathbf{2 0 0 0} * *$ & $\mathbf{2 0 0 2}$ & $\mathbf{2 0 0 3}$ & $\mathbf{2 0 0 4} \mathbf{4}^{*}$ & $\mathbf{2 0 0 5}$ & $\mathbf{2 0 0 6}$ & $\mathbf{2 0 0 7}$ \\
\hline $\begin{array}{c}\text { Compostelas } \\
\text { Issued }\end{array}$ & 2491 & 23,218 & 154,613 & 55,004 & 68,952 & 74,614 & 179,944 & 93,942 & 100,377 & 114,026 \\
\hline Year & $\mathbf{2 0 0 8}$ & $\mathbf{2 0 0 9}$ & $\mathbf{2 0 1 0 ^ { * }}$ & $\mathbf{2 0 1 1}$ & $\mathbf{2 0 1 2}$ & $\mathbf{2 0 1 3}$ & $\mathbf{2 0 1 4}$ & $\mathbf{2 0 1 5}$ & $\mathbf{2 0 1 6}$ & $\mathbf{2 0 1 7}$ \\
\hline $\begin{array}{c}\text { Compostelas } \\
\text { Issued }\end{array}$ & 125,141 & 145,877 & 272,413 & 183,366 & 192,488 & 215,880 & 237,882 & 262,447 & 277,854 & 301,036 \\
\hline
\end{tabular}

Source: Pilgrim's office Statistics, Archicompostela PEREGRINOS EN LOS ÚLTIMOS AÑOS [49,74]. * Holy Year (when St. James' Day falls on a Sunday). ** European Commission designated Santiago de Compostela as European Capital of Culture (European Communities, 2009)

While the old town of Santiago de Compostela in Spain was declared a World Heritage Site by UNESCO in 1985, the entire route of Camino de Santiago became a UNESCO World Heritage Site in 1993. The route has also been a "Cultural Route of the Council of Europe" since 1987 [75], which extends the visibility of the route as a non-religious resource to a larger traveling community. According to UNESCO [76], there are approximately 1800 buildings-religious or secular-along the route that are believed to have great historic and cultural value. In addition to these historic buildings, which are promoted by the European Union (EU) and the Spanish government in order to boost tourism, the long, scenic route itself has also been an attraction point for people seeking physical challenge and wellness [19,77]. Murray and Graham [23] view Camino as a consumptive and route-based tourism destination with a diverse set of offerings for both pilgrims and secular visitors. It has evolved into a multi-entry journey that can be taken with different modes of transportation and for different travel purposes (Table 2). Both a major pilgrimage and a UNESCO World Heritage Site, Camino has increasingly been ascribed with juxtapositional values, meanings, and motives, which may indicate not only its extra-religious function, but also its growingly indistinct perceived identity.

In spite of its significant value as a cultural, historical, and religious site, the identity crisis Camino is experiencing has not received adequate attention in tourism research. Only recently, some tourism researchers have turned their attention to the changing characteristics of religious tourism that surrounds Camino and the city of Santiago in the wake of its millennial revival $[17,19,20,51,78]$. Two important implications from these studies are that (i) motivations are increasingly diverse with more spiritual, semi-religious, or secular motives to walk on Camino as opposed to purely or traditionally religious motives [51,79]; and (ii) the identity of Camino is changing in response to the increasingly diverse attention it receives from visitors as well as commercial and political forces [17]. These studies undoubtedly provide valuable insight into how dynamic the landscape of Camino is when it comes to motivation, experience, and meaning-making. This dynamism could be associated with the so-called contemporary "post-secular" era $[17,51]$, not so much in the premise of religious reclamation as it is in its manifestations of a de-institutionalized and more "personal" religiosity $[51,80]$. Some of these recent studies use empirical data [19,51], availing valuable comparisons between the long-held theoretical or conceptual frameworks and the real experiences that take place in Camino and Santiago de Compostela. However, the use of structured methods in these studies, such as pre-determined instruments or researcher-led questioning, may bias or confine information into pre-established categories when visitors' destination-based experiences or any other mental representations are concerned [81-83]. Despite the growing interest in understanding contemporary religious travelers' motives, knowledge is still limited in terms of freely expressed motivations and experiences of visitors to a religious site. Moreover, how these motivations and experiences relate to the perceived identity of Camino as a tourism destination remains to be studied. In a relevant study, Nilsson \& Tesfahuney [51] have investigated the performativity of post-secularism in the historic city of Santiago de Compostela; in other words, the interaction between the "discursive arena" and arenas of "praxis" (p. 20). Understanding the actual dynamic relationship between what visitors experience and the identity (re)making of a religious route such as Camino may also benefit from a bottom-up approach that investigates visitors' unsolicited expressions. 
Table 2. Means of travel and motivations of Compostela recipients.

\begin{tabular}{|c|c|c|c|c|c|c|c|c|c|c|c|c|c|c|c|c|c|}
\hline & Year & 2011 & $\%$ & 2012 & $\%$ & 2013 & $\%$ & 2014 & $\%$ & 2015 & $\%$ & 2016 & $\%$ & 2017 & $\%$ & 2018 & $\%$ \\
\hline \multirow{4}{*}{$\begin{array}{l}\text { Means of } \\
\text { travel }\end{array}$} & On foot & 153,078 & 16.00 & 164,749 & 85.60 & 188,187 & 87.17 & 210,939 & 88.67 & 237,707 & 90.19 & 254,025 & 91.42 & 278,490 & 92.51 & 306,064 & 93.49 \\
\hline & By bicycle & 29,948 & 83.00 & 27,406 & 14.24 & 26,649 & 12.34 & 25,325 & 10.65 & 25,343 & 9.66 & 23,347 & 8.40 & 21,933 & 7.29 & 20,787 & 6.35 \\
\hline & On horseback & 314 & 0.19 & 281 & 0.15 & 977 & 0.45 & 1520 & 0.64 & 326 & 0.12 & 342 & 0.12 & 417 & 0.14 & 318 & 0.10 \\
\hline & Wheelchair & 11 & 0.01 & 22 & 0.01 & 66 & 0.03 & 98 & 0.04 & 71 & 0.03 & 125 & 0.04 & 43 & 0.01 & 79 & 0.02 \\
\hline \multirow{4}{*}{$\begin{array}{l}\text { Motivations } \\
\text { of } \\
\text { Compostela } \\
\text { recipients }\end{array}$} & $\begin{array}{l}\text { Religious and other } \\
\text { reasons (cultural) }\end{array}$ & 93,156 & 51.00 & 101,155 & 52.56 & 117,788 & 54.56 & 120,409 & 50.62 & 141,967 & 54.09 & 132,660 & 47.74 & 147,662 & 47.39 & 156,720 & 47.87 \\
\hline & Religious & 78,972 & 43.00 & 79,477 & 41.30 & 86,284 & 39.97 & 101,012 & 42.46 & 99,671 & 37.98 & 122,973 & 44.26 & 130,831 & 43.46 & 140,037 & 42.78 \\
\hline & $\begin{array}{l}\text { Not religious } \\
\text { (cultural) }\end{array}$ & 11,250 & 6.00 & 11,826 & 6.14 & 11,807 & 5.47 & 16,461 & 6.92 & 20,809 & 7.93 & 22,221 & 8.00 & 27,543 & 9.15 & 30,621 & 9.35 \\
\hline & Total & 183,378 & 100 & 192,458 & 100 & 215,879 & 100 & 237,882 & 100 & 262,447 & 100 & 277,854 & 100 & 301,036 & 100 & 327,378 & 100 \\
\hline
\end{tabular}




\subsection{Motivational Landscape of a Religious Route: A Push-Pull Perspective}

Motivation has long been considered the main determinant of travel behavior [84] and psychological needs have traditionally been linked to the motivational factors for travel [85-88]. However, travel motivations are complex, multi-faceted phenomena and several different motivation theories and conceptual frameworks have been suggested to explain them [89-92]. In the same vein, the main motivation of pilgrimage can be said to lie in religious and spiritual reasons, but the specific components of this motivation would vary greatly depending on personal aspects [93].

One prominent conceptual framework-the push and pull framework-is frequently used by tourism researchers to investigate tourist behavior and motives underneath their needs and desires $[59,60,94]$. According to this framework, push motivations refer to the inner force within the traveler that leads to the decision to undertake a journey, such as the need or desire to escape from everyday life. On the other hand, pull motivations emerge in response to external factors, such as the features or attributes of a destination. In tourism research, the needs for escape, relaxation, relation, knowledge, self-esteem, and entertainment have often been identified as push factors, while climate, scenery, attractions, and airfare have emerged as common pull factors [94-97]. Studies on push and pull factors of motivation have also shown that these factors can sequentially or concurrently drive any travel behavior [98-100].

From an epistemological perspective, the push and pull framework can help exploring the travel motivations for a religious site in the same way it does for other forms of tourism. Furthermore, the push and pull framework may prove useful in delineating the characteristics of religious tourism as a so-called midpoint between sacred and secular travel. As suggested by Cohen [72], existential tourists' quest for a spiritual center might be strongly driven by inner goals, while the pleasure sought by recreational tourists is more externally defined. From a push and pull perspective, what this categorical difference might imply is that a motivational category might not only characterize one tourist type more than the other (e.g., existential tourists being driven by push factors more than recreational tourists), but differences might manifest intra-categorically (existential tourists being "pulled" to spiritual destinations while recreational tourists are "pulled" to resorts).

Furthermore, the utility of the push-pull framework might be more evident when the perceived identity of a religious site such as Camino de Santiago is in question. It might be an impossible (and impertinent) mission to try to resolve the debate on where pilgrimage ends and tourism starts, or what constitutes religiosity in contemporary society. However, a push-pull framework might provide a picture of Camino in broad strokes as it pertains to the visitors' point of view; it can be argued that it has been the the inner-focused motivations that have made Camino a pilgrimage destination for over a millennium, whether they be purely religious or a contested area of cultural and political influence $[17,22,23]$. Hence, the implications of the push-pull framework might be cautiously suitable to explore various motivations for traveling to Camino. One can easily imagine various internally driven motivations for Camino that may be deemed outside the conventional definitions of religiosity (e.g., escape from the mundane) or too materialistic for even the most inclusive conceptualizations of spirituality. In fact, internal motivations might be too complex, multi-layered, or ambivalent for such distinctions or subcategories. Therefore, existence or prevalence of inner-focus does not necessarily indicate religious motives or religious identification of Camino. However, its scarcity or absence might at least indicate a shifting identity among today's fluid, pluralist, and ambiguous interpretations of religion, spirituality, and secularity.

\subsection{Research Purpose and Rationale for Thematic Analysis}

This study aims to understand the motivational characteristics of Camino travelers, as well as the perceived identity of the route as it transforms a pilgrimage center to a heritage destination.

The specific focus of this study is the Camino de Santiago, in order to understand travelers' experience, identify their motivation as modern pilgrims or heritage tourists, and compare these experiences and motivations to identify what major motivational groups might be relevant to the 
identity of such a destination. Within this aim, the researchers primarily seek to determine whether visitors perceive their sacred, secular, or otherwise meaningful experience in Camino de Santiago to be driven by inner or external motives.

The push and pull framework of motivation was used as the guiding theoretical framework to thematically analyze visitors' written accounts in the online communities. Thematic analysis is a method in which the researcher analyzes qualitative data for underlying themes without an a priori epistemological theory that underlies most methodologies [101-103]. While inductive thematic analysis resembles a grounded theory approach in holistically constructing and interpreting the reality of a specific situation based on the accounts of the people who experience or are at the center of that situation [104-106], theory-driven thematic analysis leverages existing theories or conceptual frameworks relevant to a research purpose to narrow its content search and/or coding processes for specific themes [103]. In other words, theory-driven thematic analysis trades a descriptive breadth of the data for a focused response to a research question without losing epistemological freedom. Therefore, theory-driven thematic analysis was considered a suitable method to analyze, code, and interpret motivational content guided by the implications of the push-pull framework and pilgrimage-tourism continuum. Despite the involvement of pre-existing constructs in the analysis, the independence of content sources from the researchers' influence helped maintain the centrality of participant experiences and minimize the analytic bias in this study.

\section{Method and Analysis}

\subsection{Data Collection}

Online accounts generated by Camino travelers in the form of electronic diaries or journals were chosen as the content sources for this study, as these sources have the potential to reflect writers' freely expressed thoughts, impressions, and feelings [107,108]. As the purpose of this research was to explore the de-facto motivational variation among tourists with minimal bias from researchers or their questions, user-generated content on the Internet was considered a suitable source for this study.

Electronic journals were collected from two online communities, an independent online community called Camino de Santiago Forum and one group forum created under TripAdvisor. Trip Advisor (www.tripadvisor.com) groups are visited by many types of travelers and information seekers owing to the commercial popularity of the website. TripAdvisor claims to be the largest travel community in the world, having a monthly average of 390 million unique visitors and a total of 435 million reviews on 7 million attractions, hotels, and restaurants [109]. Moreover, several academic studies have regarded TripAdvisor as one of the most widely utilized online travel communities [110,111], as well as one of the social media platforms that has a great influence on tourists' travel decisions [112]. Camino de Santiago Forum (www.caminodesantiago.me) is mainly frequented by those motivated by religious/spiritual interests. One of the authors had first learned about this forum during her walk in Camino through word of mouth with other pilgrims. The site has been online since 2004 with active daily international traffic, and is owned and maintained by a local businessowner. Membership to the forum site is free, although donations are accepted to remove ads.

A total of 116 written accounts from TripAdvisor [113] from September 2010 to October 2014 and a total of 87 written accounts from Camino de Santiago Forum [114] from February 2011 to October 2014 were collected. No specific agenda or selection criteria were employed when accounts from TripAdvisor and Camino de Santiago Forum were collected, except that the written accounts were independent expressions about Camino with substantial content. Independence meant that main entries, as opposed to direct responses to travel-related queries (about transportation, accommodation, directions, and so on), were selected to ensure accounts were free expressions, minimally guided or led. Substantiality referred to the fact that accounts had sufficient content to analyze (usually in multiple sentences). Hence, purposive sampling was utilized in this study to ensure the accounts specifically belonged to individuals who traveled Camino at least once, were expressed freely, and pertained to 
their experience(s) in Camino. No demographic factors or personal information other than user names were accessible to the researchers at any time. All inferences regarding visitors' motivational, religious, or secular characteristics and/or background were solely based on the information they shared on their posts. For ease of following, account excerpts used to illustrate points in this narrative are numbered in order of their appearance $(\mathrm{A} 1, \mathrm{~A} 2, \mathrm{~A} 3, \ldots)$.

\subsection{Data Analysis}

A theoretical thematic analysis was used to review and evaluate the data obtained for this study. The content-analytic steps followed the coding phases and respective techniques commonly utilized in similar qualitative-analytic studies; that is, open coding, axial coding, and theoretical coding [34]. No specialized software was used and all coding was done manually. In the first phase of open coding, line-by-line coding was used to explore initial segments of data. The first phrase yielded 168 open codes. Some of the prominent codes that emerged from this phase were industrialized, (end of) holiness, emotional change, unique holiday, travel agency, organized trip, adventure, escape, personal reflection, satisfaction, getting away, physical training, engaging with others, recommendations, desire to revisit, discomfort, and fading traditions. In the second phase, these open codes were categorized into subcategories based on the resemblance of the initial unit. As a result, the open codes centered on 27 axial codes such as challenge, accomplishment, spirit, adventure, training, silence, vacation, achievement, camaraderie, health, transformative experience, and learning. Finally, the theoretical coding was employed to understand the variations in motives and sketch a motivational landscape of Camino with respect to the push and pull framework. For further trustworthiness steps, both stepwise replication and code-recoding were utilized by the researchers. The results from all three coding phases were consistent between the researchers.

\section{Findings}

\subsection{Camino as a Pull for the Non-Religious: Cultural, Natural, and Service-Related Attributes}

In general, visitors who focused on describing historical and cultural attractions, picturesque sceneries, quality of accommodation and dining, and the service by travel agents tended not to mention or discuss an overt religious or spiritual experience.

"... to see many different views of a very pretty part of the world at a great time of year; to experience multiple little historical journeys through museums, cloisters and churches; to taste fabulous food; to enjoy fresh air and highly manageable doses of gentle but healthy exercise; to stay in beautiful homes, farms, guest houses and hotels; and to reflect on your life, if you want to ... "

(A1)

"This would have no influence on my walking the any of the routes, but it does mean something for some people - quite a few really ... ... Only twice along the way did I get into religious conversations." $(A 2)$

"Some do it for religious or spiritual reasons while others do it to take in the cultural and historical aspects of northern (and especially northwestern) Spain. Still others do it simply because it is a fantastic outdoor hike..."

They illustrated their experience as being enjoyable, unforgettable, and pleasurable, and mentioned different types of personal gain, benefit, or fulfillment from completing the route, such as achievement, pride, and accomplishment:

"My wife and I completed the Camino de Santiago on September 10, 2011...after walking 800kms over 35 days. This is one of the most incredible things we have ever done....the sense of accomplishment, the 
amazing people you will meet from all walks of life, and the camaraderie that develops with them, the great wine, the friendly (mostly) a[u]bergue owners...."

(A4)

These visitor accounts were mostly encountered on TripAdvisor. Descriptions such as "best-holiday", "truly amazing", "best experience ever", "best trip ever", "life-changing experience", and so on were common among these accounts. Even though a spiritual dimension or quality to the experience was questionable at best in these accounts, a strong emotional meaning was highly prevalent. Their journey might not be the same spiritual journey as experienced by the religiously-motivated; however, the content of "spiritual" ascribed to the journey as well as its intensity varied for different people.

"This is not an easy 'holiday' it is a challenging hike, but a very rewarding one ... . I would recommend this trip to anyone who feels they are fit enough to do it, it will change your life and attitude to life in general"

"We walked the last 100km from Ferrieros to Santiago de Compoestela Every single one of us feel so amazing and changed on a mind body and spiritual level. Truly a life changing experience."

(A6)

"... when you complete the way and enter in Santiago de Compostela: Somewhere deep inside you get a little sad wishing the journey were not over, you want to continue on walking, you want to be headed somewhere. This emotion is shared by many, many, many 'peregrinos' (pilgrims). True the journey is not really over when you get there but I do not intend to romanticize the experience too much or spoil your encounter with these emotions!"

"Doing this is personal, lots of reasons, religious, spiritual, or merely tourist. it depends on your being open mindedness. it is one step at a time. somehow after doing this walk, something inside changes ..."

People with no explicit religious motive might not have had a sense of a traditionally defined "faith-based" spiritual experience; nevertheless, for some, the journey seemed to instigate a similar "movement" or sentimentality in them. For instance, one visitor who met the locals felt sad for the government so much that he was " ... interested in pouring new money into the Camino de Santiago ..." to contribute to its development as "a tourist attraction".

From Turner's [40] perspective, even though the commercialization of pilgrim sites is seen to be a modern transformation, pilgrimage has long been organized and consumed. However, the local and regional authorities are in the front line to make both the organization and consumption a sustained cycle. While the awareness of the mass commercialization of Camino de Santiago was a salient notion in the accounts, the individuality of the experience was also central to many of them, which seemed, at times, to buffer challenging aspects of the walk.

"Was it a 'spiritual journey' or just a long walk in Spain? It was certainly the most remarkable journey of my life, not really a 'vacation.' ... . You will almost certainly experience pain and discomfort. You could get hurt or sick. You may not be able to complete the journey to Santiago. That, in my opinion, is part of learning to trust and accept." 
"You meet yourself on the Camino. You find out what you like and what you don't like. How you interact with people. What your physical limits are. The things you miss the most from home and the things that you don't. How you overcome difficult situations and obstacles on the way. The road is rough, but the end is very rewarding."

(A10)

Lack of an explicit religious or spiritual motive in personal terms did not prevent expressions of worry regarding the overuse of the route and its potential effects on the pilgrims.

"... words will not allow me to do this pilgrimage justice ... ... . If you are going purely as a walker have respect for the pilgrims whose reasons for being there are many. If your intention is to walk at least part of this wonderful journey travel light, respect your feet and be patient."

(A10)

"The pilgrim doesn't have to be Catholic, or even Christian. But I deeply believe its important to approach the path with a measure of understanding and respect for these historical institute, and what they have meant in the experience of the thousands who have come before-and the many who still walk the Way of St. James with a soul devoted to its redemptive effects."

(A11)

Secular tourists recommended others to show respect and observe etiquette towards others, especially pilgrims. In sum, these travelers seemed to be conscious of and attracted by the authentic religious character of Camino as well as Santiago de Compostela, and showed sensitivity towards others with religious motives. However, they did not manifest a religious motive for their own travel. From one perspective, these tourists could be classified as "knowledge-based" [30,58] religious tourists as they are primarily motivated and intrigued by the pull factor of Santiago. However, from a more traditional viewpoint — such as the one described by Rinschede [31]—it would be difficult to classify them under religious tourism, which should be at least partly undertaken for religious reasons.

\section{2. "Push" for Camino: Institutional Religiosity or Personal Spirituality?}

Religion or religiosity was among the most influential motivations among those driven by a push factor. An inner, metaphysical motivation was manifest at varying intensities among many traveler accounts when they described Camino as " ... a wonderful spiritual experience", " ... a relationship to our Creator", or " ... very inspirational to me with my religion." These travelers expressed psychological motives as well as inner forces with explicit references to their religious backgrounds, spirituality, or "quest" for inner peace. Despite the shared "inner" quality, the distinctions between conventional, institutionalized religiosity, and more personalized interpretations or spirituality were also salient to some travelers. One Methodist pastor mentioned the following:

"The modern Camino does seem to be bathed in contemporary spirituality, though. Perhaps it was because I am a pastor, but I had many, many conversations with people (mostly women) about spirituality. I had some arguments, too, about whether it was possible to be both religious and spiritual! Many people had read Paulo Coelho and were looking for a mystical experience. Many find that the discipline of the walk itself becomes a spiritual exercise."

For many, the distinctions between religious and spiritual were as central to their experience, as they were, perhaps, to their self-identity.

"... I considered it a pilgrimage. I am Catholic and for me the aim of the pilgrimage was a religious one."

(A13) 
"I have always taken the religious motivation to mean spiritual rather than strictly catholic ..."

(A14)

"... Camino is for everyone and for whatever reason these days. However, the Catholic Tradition upon which the Camino de Santiago was founded does not change.... ."

(A15)

"It was a fantastic and rewarding experi[e]nce to become a pilgrim at last. At 60 yrs old, I was by far, not the oldest nor the youngest on the walk. I felt blessed and honoured to be able to experi[e]nce the walk that millions have done before me."

(A16)

For others, the distinctions either did not matter or did not mean exclusion from one another:

".. I have always felt that we are all "spiritual" in our own way, whether we believe it or not..."

"This is a special walk, yes, a pilgrims walk but a walk with like-minded people, open, friendly, honest, from all over the world, young and old, who all have one goal: to take part in this beautiful walk, to partake of the synergy, the energy, the vibe, to experience something of the spiritual, to take time out for oneself and to reach the goal: Santiago."

The implication that pilgrimage requires the primacy of a religious motive was more obvious in other posts where strong disapprovals were voiced regarding "tourists" seeking comfortable ways of completing the journey:

"These tourists are the farthest thing from pilgrims since they reserve all the hostels and hotels (in advance) and they send their bags by bus to their next destination every day. The true spirit of the Camino has been robbed by these people ... . Apart from being frustrated by the people who rob the spirit of the Camino, it was a great experience and I would recommend it to anyone."

"There is no shame in not having a religious or spiritual motivation as a basis for completing the Camino. But if you do not have such, why would you want a certificate declaring that you had? Makes no sense."

Many travelers with religious motives did not indicate an explicitly extrinsic phenomenon that could be categorized as a pull factor. They tended to distinguish themselves as pilgrims compared to others who, in their view, did not show or have religious motivations. Even though almost all religious or spiritual motives could be generally categorized under push factors, not all push factors mentioned in the accounts were primarily religious. Escape was also mentioned as a push factor; one traveler recommended Camino to those with the "need to get a break from modern day stresses and enrich your health, happiness and sense of well-being".

In general, religious travelers were mostly driven by push factors, and rarely by pull factors, while non-religious or secular travelers were motivated by both push and pull factors. In accordance with Smith [58], those who traveled with push factors and distinguished the religiousness of their motives in their posts could be identified as pilgrims in a sacred journey, or, in broader terms, as tourists travelling in the "existential mode" [40]—a mode analogous to pilgrimage. 


\section{Discussion: Is Camino de Santiago a Religious or Secular Site?}

According to the personal accounts analyzed in this study, Camino de Santiago appears to be a complex site associated with cultural, historical, and spiritual meanings, rather than solely religious meanings. The official records of Compostelas reveal that various motivations exist among the travelers, and intermediate categories such as "religious and other" are more prevalent than exclusive categories such as "purely religious" or "purely non-religious". Personal accounts seem to validate these statistics; Camino de Santiago may be perceived as a religious tourism site by many who seem to be motivated partly by religious factors and partly by non-religious factors. Even though the personal accounts used in this study were not easily categorizable into clear motivational categories because of narrative styles and differences, purely religious comments were scarce. Instead, there was an abundance of reflection on scenery; accommodation; food; and how unforgettable, pleasurable, enjoyable, healthy, or physically challenging the route was. Also, many comments on the TripAdvisor site made references to tourism services (e.g., accommodation, tours). For many travelers, the challenge of Camino de Santiago was more physical than traditionally religious. They indicated prior knowledge of the walk not being an easy holiday. Yet, many experienced a sense of accomplishment and achievement by completing the walk. Despite the challenges, the majority said that they would do it again. The unique "escape" from everyday life that Camino represented was important for them:

"Taking the walk is not only a time for enjoyment, but a rare opportunity to escape the mundane or the busy lives we lead."

(A22)

This, perhaps, could be seen as an indicator that for most people, the Camino de Santiago was perceived primarily as a secular tourism destination. However, categorizing what appears to be non-religious in conventional terms as necessarily secular or opposite of religious would be an inaccurate account of travelers' expressions. First, despite the satisfaction at the end, the fact that Camino was not a purely pleasurable or enjoyable experience does not fit the definition of typical leisure travel. Second, and perhaps more importantly, was Camino's purpose or meaning; for some, this meaning was what made the walk a transformative, "life-changing", or "rewarding" experience and for others, it was what made the challenges bearable or even essential.

Personal meanings, as well as metaphysical or spiritual gains that surround Camino are particularly important when the arguments on "post-secularism" are considered. As Nilsson and Tesfahuney [54] indicate, the idea of religion in post-secular society might be more personalized and fluid as opposed to the conventional and institutionalized. In other words, in the post-secular society of today, the personalized and fluid concept of religion may not necessarily be an alternative to conventional religiosity, but one of its modern variations. In this respect, it may be an imposition rather than a definition to draw a line between religiosity and spirituality when the identity of Camino is concerned. In fact, many travelers indicated an understanding of religion that is inclusive of spirituality and personal meanings. To them, religious motivation meant "spiritual rather than strictly catholic", and everyone was "spiritual in [their] own way". Moreover, Camino's perceived identity was not inhibitive, but facilitative of spiritual experiences of this kind. Several travelers emphasized having attended the evening masses even though they were "not religious" or had "no religious motivation for this trek", only to find them "very interesting", "very moving", or having ". . a sense of solitude and gratitude that was peaceful". However, many referred to "Camino the road" or "Camino the journey" as the source of this spiritualization:

"... a journey where who you are and even your name does not define you. On the way you have conversations with people for about 30 min to an hour without even knowing each others names. It does not matter, what matters is the journey you are both on. It is the same journey, and yet it is a completely different walk for each person you meet."

(A23) 
Camino had "... sense of moving living community day after day of genuinely concerned souls from all around God's Green Earth". In the words of a spiritually-motivated woman traveler, her husband's cultural motives did not preclude him seeing "many inexplicable things", through which

"... his original perception that we make our own lives has been changed by the realization that there is, indeed, a force greater than ourselves at wo[r]k. Even his reply when asked for his reason for doing the Camino testifies this: having been involved in a war many years ago, and all it entails, he saw his personal Camino as an atonement for the horrors he encountered."

Another traveler shared a similar experience:

"My companion was not Catholic but still managed to be blown away by the Mass for Pilgrims in the Cathedral in Santiago (= St James) de Compostella (=field of stars)"

(A25)

Camino was a unifying walk where one could meet "... an amazing range of people from all over the world ..." who shared the goal "... to partake of the synergy, the energy, the vibe, to experience something of the spiritual" and made "... lifelong friendships as a result". Even the ambivalent feeling of reaching Santiago, one that incorporates both joy and sadness, was shared by "many, many 'peregrinos [pilgrims]", which indicated an identity of Camino that may be distinct even from its endpoint:

"As you enter the Porta do Camiño which leads you to the Cathedral and center of Santiago, some of the spirit of The Camino comes back. For me, it was the journey and not the destination that satisfied me the most. I just wanted to keep on going, me and my two feet even after I had that third 'compostela' aka credential in hand."

When this "spiritual" aspect of Camino is taken into account as a modern extension or variation of religiosity, the secularity of the road may be overstated. Smith [58] delineates the differences between secular and religious traveler in her pilgrimage-tourism continuum, and specifies five points: (a) pious pilgrim, (b) pilgrim > tourist, (c) pilgrim = tourist, $(\mathrm{d})$ pilgrim $<$ tourist, and (e) secular tourist. However, she does not necessarily distinguish between spirituality and religiosity with respect to their institutionalization versus personalization. In other words, the spiritual meaning of Camino may not necessarily preclude or diminish its identity as a religious place. While for some travelers, Camino is clearly a non-religious place whose motivations for " ... walking the [C]amino were cultural [i]n the first place" or for the "... art and history [which is] priceless", for many more, Camino represents something spiritual, even if that "something" may vary greatly. In other words, the core of the spiritual identity of Camino that has resisted the test of time throughout centuries carries on. Thus, according to the authors, Camino is best associated with the (b) point of the continuum, where its adherents are more religious or spiritual pilgrims than purely secular tourists (Figure 1).

\section{Conclusion and Limitations}

The motivation and experience of travelers walking the Camino de Santiago route in this study were explored and analyzed through the push and pull theoretical framework. The push and pull theoretical framework helped to identify the underlying differences as well as similarities between the religious and non-religious travelers. In this study, religious travelers were found to be motivated mostly by push factors, while non-religious travelers were motivated by both pull factors. The subsequent goal was to understand what this motivational and experiential mix surrounding Camino means for its contemporary identity. The findings were, therefore, compared to Smith's [58] pilgrimage-tourism continuum. 
The fact that self-proclaimed "religious" travelers were primarily motivated by traditional or conventional religious reasons, the spiritual benefits that they seek, as well as the personal meaning of their overall experience supports the view that the religious beliefs that a traveler brings to the pilgrimage are the essential elements of the pilgrim experience [115]. For these travelers, Camino remained to be what it has always been-a sacred pilgrimage site. On the other hand, the accounts by the self-proclaimed "non-religious" travelers yielded more complex data. In terms of the ex ante motivations that caused them to take the walk, they were largely driven by pull factors such as natural/historic/physical aspects of the route. However, the actual experience of many non-religious travelers did not necessarily remain within the seemingly "secular" territories, and gained a "spiritual" quality through interaction with others, self-reflection, or introspection. This spiritual experience was different from the conventional religious experience in the sense that it was more personal and self-interpretive; largely consistent with Nilsson and Tesfahuney's [51] argument for the view of religion in the post-secular. From this perspective, "secular" is already a part of the "religion" of the contemporary traveler, making Camino a "religious" destination in their own and personal terms, be it wholly or partially. Therefore, it was concluded that Camino's identity was perceived to be more religious than non-religious, even though purely non-religious attention on Camino is growing.

As mentioned earlier, the meaning of travelers' perceptual world-including expectations, motivations, experiences, or even retrospection—for the identity of a religious destination such as Camino may not reducible to an account of tourist gaze. Changes in the identity perception of Camino may not be a mere outcome of the touristification process, where places once only experienced by "insiders" or locals are gradually experienced by "outsiders" or tourists. On the contrary, the dynamic behind Camino's identity change might be an intragroup dynamic between the traditional and modern pilgrims. Camino has always been traveled. In fact, Camino would not have existed without the pilgrims-its earliest travelers. As Gonzalez [17] discusses, the religious significance of Camino-or even the city of Santiago de Compostela - was tied to the quest for its recognition by the Vatican as a place worthy to be visited and venerated by Christians. Ultimately, it was the decision of the church that approved its pilgrimage-worthiness and the consequent influx of pilgrims that gave its religious significance, making the sacred travel inseparable from its religious value. Modern travelers, however, live and express their religiosity in a more personal and interpretive way, which was encompassing or inclusive, rather than exclusive, of the cultural and natural aspects of Camino.

It is also important to note that the "spiritual religiosity" of the modern traveler did not necessarily manifest itself as a stark contrast to traditional religiosity. The inclusivity of modern spirituality also extended to traditional forms and rituals of religion. Many non-religious travelers found spiritual meaning in their attendance to masses and churches, as well as conversations and interactions with the religiously motivated travelers. However, calls for respect and understanding towards these elements were frequent among the accounts by non-religious travelers. They were mostly conscious, and some even protective of the religious meaning(s) behind Camino that was independent from their own interpretations. This consciousness may be different than the post-secular account of visitors to Santiago de Compostela as discussed by Nilsson and Tesfahuney [51].

Even though the pull motives by secular travelers comprised a considerable part of the motivational mix, push factors or internally driven motivations emerged as a common element across religious, spiritual, and secular travelers. On the one hand, this might signal a somewhat diluted religious meaning and perceived identity of the route in comparison to its early historical position. On the other hand, inner goals seem to continue to represent a greater motivational variation across different groups in a world where the religious and secular are increasingly ambiguous labels. In turn, Camino may not necessarily possess its so-called conventionally religious identity, but its symbolic connection to inner goals prevails as a unifying force among a greater variety of travelers. This inclusivity might be the most prominent evidence for Camino's social sustainability $[25,27,28]$.

Lastly, the results were also in line with Crompton's conclusion that [60] consumers motivated by socio-psychological motives seek unique experience and exploration of the self from a destination that 
is physically and socially different from the mundane environment. A common theme that emerged from both religious and non-religious accounts was that regardless of cultural or religious factors, nationality, age, or specific travel purposes, all seemed to recommend this journey to others and many would do it again. Loyalty to Camino, evident from the increasing number of visitors every year, suggests that its identity representations will be increasingly communicated and continue to evolve.

It is, of course, not possible to determine if Camino de Santiago is a pilgrimage site or a secular tourism destination. Does it weigh more as a Christian destination or a World Heritage Site? The true meaning and value of Camino de Santiago is hidden in experiences. According to the results of this study, the Camino de Santiago is somewhere between a pilgrimage and religious tourism site on Smith's continuum. However, this study was based on limited data and employed a qualitative approach in order to gain a deeper understanding of how travelers on the route perceived and experienced the site, and how these experiences compared and contrasted between the religiously motivated and the secular travelers. In the future, the findings can significantly be enhanced with real interviews conducted on the site.

There are also some limitations to the study. Online and secondary nature of the content prevented a verification of "religious" versus "secular" travel motives or other demographic information unless this information was readily available in the content. The sample was selected from two websites based on their relevance and popularity. However, there are many different websites and forums where visitor accounts can be found. Moreover, such data only cover active users of the Internet.

Further studies may overcome these limitations and continue to explore the meaning and identity of Camino de Santiago for its contemporary adherents. In addition to travelers, volunteers and residents should also be interviewed for deeper and more diverse insights into what the route truly stands for.

Researchers' Backgrounds: Both researchers come from a tourism background, with PhDs in tourism. Both worked in governmental tourism institutions from two different countries. One identifies as Catholic, while the other does not. The Catholic researcher has previously walked the entire Camino for a month.

Author Contributions: Conceptualization, H.K.; Data curation, S.Y.; Investigation, H.K. and S.A.; Methodology, H.K. and S.Y.; Project administration, S.Y.; Supervision, S.A.; Writing—original draft, H.K. and S.A.; Writing-review \& editing, H.K. and S.Y.

Funding: This research received no external funding.

Conflicts of Interest: The authors declare no conflict of interest.

\section{References}

1. Urry, J.; Larsen, J. The Tourist Gaze 3.0; SAGE: London, UK, 2011; ISBN 1446250024.

2. Buckley, R. Evaluating the net effects of ecotourism on the environment: A framework, first assessment and future research. J. Sustain. Tour. 2009, 17, 643-672. [CrossRef]

3. Weaver, D.B.; Lawton, L.J. Twenty years on: The state of contemporary ecotourism research. Tour. Manag. 2007, 28, 1168-1179. [CrossRef]

4. Fennell, D.A. Ecotourism, 3rd ed.; Routledge: New York, NY, USA, 2008; ISBN 9780415829656.

5. Kurtzman, J.; Zauhar, J. Sports tourism consumer motivation. J. Sport Tour. 2005, 10, 21-31. [CrossRef]

6. Smith, A. Reimaging The City: The Value of Sport Initiatives. Ann. Tour. Res. 2005, 32, 217-236. [CrossRef]

7. Biran, A.; Poria, Y.; Oren, G. Sought Experiences at (Dark) Heritage Sites. Ann. Tour. Res. 2011, 38, 820-841. [CrossRef]

8. Inglis, D.; Holmes, M. Highland and other haunts: Ghosts in Scottish Tourism. Ann. Tour. Res. 2003, 30, 50-63. [CrossRef]

9. Strange, C.; Kempa, M. Shades of dark tourism: Alcatraz and Robben Island. Ann. Tour. Res. 2003, 30, 386-405. [CrossRef]

10. Ooi, N.; Laing, J.H. Backpacker tourism: Sustainable and purposeful? Investigating the overlap between backpacker tourism and volunteer tourism motivations. J. Sustain. Tour. 2010, 18, 191-206. [CrossRef] 
11. Andereck, K.; McGehee, N.G.; Lee, S.; Clemmons, D. Experience Expectations of Prospective Volunteer Tourists. J. Travel Res. 2012, 51, 130-141. [CrossRef]

12. Novelli, M. Niche Tourism: Contemporary Issues, Trends and Cases; Elsevier: Amsterdam, The Netherlands, 2005; ISBN 075066133X.

13. Moutinho, L.; Vargas-Sanchez, A. Strategic Management in Tourism, 3rd ed.; CABI Tourism Texts: Boston, MA, USA, 2018.

14. Poon, A. The 'new tourism' revolution. Tour. Manag. 1994, 15, 91-92. [CrossRef]

15. Buhalis, D.; Costa, C. Tourism Management Dynamics: Trends, Management, and Tools; Elsevier Butterworth-Heinemann: Oxford, UK, 2006; ISBN 0750663782.

16. Stamboulis, Y.; Skayannis, P. Innovation strategies and technology for experience-based tourism. Tour. Manag. 2003, 24, 35-43. [CrossRef]

17. Lois González, R.C. The Camino de Santiago and its contemporary renewal: Pilgrims, tourists and territorial identities. Cult. Relig. 2013, 14, 8-22. [CrossRef]

18. Lopez, L.; Nicosia, E.; González, R.C.L.; Lopez, L.; Nicosia, E.; Lois González, R.C. Sustainable Tourism: A Hidden Theory of the Cinematic Image? A Theoretical and Visual Analysis of the Way of St. James. Sustainability 2018, 10, 3649. [CrossRef]

19. Amaro, S.; Antunes, A.; Henriques, C. A closer look at Santiago de Compostela's pilgrims through the lens of motivations. Tour. Manag. 2018, 64, 271-280. [CrossRef]

20. Lois-González, R.C.; Santos, X.M. Tourists and pilgrims on their way to Santiago. Motives, Caminos and final destinations. J. Tour. Cult. Chang. 2015, 13, 149-164. [CrossRef]

21. Santos, X.M.; Lopez, L. Tourism Policies in a WHC: Santiago de Compostela (Spain). Int. J. Res. Tour. Hosp. 2015, 1, 1-8.

22. Pack, S.D. Revival of the Pilgrimage to Santiago de Compostela: The Politics of Religious, National, and European Patrimony, 1879-1988. J. Mod. Hist. 2010, 82, 335-367. [CrossRef]

23. Murray, M.; Graham, B. Exploring the dialectics of route-based tourism: The Camino de Santiago. Tour. Manag. 1997, 18, 513-524. [CrossRef]

24. Sánchez y Sánchez, S.; Hesp, A. The Camino de Santiago in the 21st Century: Interdisciplinary Perspectives and Global Views; Sánchez y Sánchez, S., Hesp, A., Eds.; Routledge: London, UK, 2015; ISBN 1317485025.

25. Ritchie, J.R.B.; Crouch, G.I. The Competitive Destination: A sustainable Tourism Perspective; CAB International: Cambridge, MA, USA, 2003; ISBN 085199847X.

26. Kastenholz, E. “Management of Demand” as a Tool in Sustainable Tourist Destination Development. J. Sustain. Tour. 2004, 12, 388-408. [CrossRef]

27. Hall, C.M. Crisis events in tourism: Subjects of crisis in tourism. Curr. Issues Tour. 2010, 13, $401-417$. [CrossRef]

28. Kastenholz, E. 'Cultural proximity' as a determinant of destination image. J. Vacat. Mark. 2010, 16, $313-322$. [CrossRef]

29. Page, S.; Ateljevic, J. Introduction. In Tourism and Entrepreneurship: International Perspectives; Page, S., Ateljevic, J., Eds.; Butterworth-Heinemann: Oxford, UK, 2009; pp. 1-6. ISBN 0750686359.

30. Jackowski, A.; Smith, V.L. Polish pilgrim-tourists. Ann. Tour. Res. 1992, 19, 92-106. [CrossRef]

31. Rinschede, G. Forms of religious tourism. Ann. Tour. Res. 1992, 19, 51-67. [CrossRef]

32. Swarbrooke, J.; Horner, S.; Horner, S. Consumer Behaviour in Tourism, 2nd ed.; Routledge: London, UK, 2007; ISBN 9780080466958.

33. UNWTO. Tourism Can Protect and Promote Religious Heritage. Communications. Available online: https: //media.unwto.org/press-release/2014-12-10/tourism-can-protect-and-promote-religious-heritage (accessed on 15 June 2019).

34. Jackowski, A. Religious Tourism-Problems with Terminology. In Peregrinus Cracoviensis, Krakow: Institute of Geography; Jackowski, A., Ed.; Jagillonian University: Kraków, Poland, 2000.

35. Richards, G. Cultural Tourism: Global and Local Perspectives; Haworth Hospitality Press: New York, NY, USA, 2007; ISBN 0789031175.

36. Kurrat, C. Biographical motivations of pilgrims on the Camino de Santiago. Int. J. Relig. Tour. Pilgr. 2019, 7, 11-18.

37. Bideci, M.; Albayrak, T. Motivations of the Russian and German tourists visiting pilgrimage site of Saint Nicholas Church. Tour. Manag. Perspect. 2016, 18, 10-13. [CrossRef] 
38. Genoni, P. The Australian Way: Transnational Flows and the 21st Century Camino. In The Camino de Santiago in the 21st Century: Interdisciplinary Perspectives and Global Views; Sánchez y Sánchez, S., Hesp, A., Eds.; Routledge: London, UK, 2015; pp. 172-193. ISBN 9781138892484.

39. Sánchez y Sánchez, S. Lost and Found: Material Culture and Personal Transformation on the Camino de Santiago. In The Camino de Santiago in the 21st Century: Interdisciplinary Perspectives and Global Views; Sánchez y Sánchez, S., Hesp, A., Eds.; Routledge: London, UK, 2015; pp. 147-171. ISBN 1317485025.

40. Turner, V.W.; Turner, E.L.B. Image and Pilgrimage in Christian Culture: Anthropological Perspectives; Columbia University Press: New York, NY, USA, 1978; ISBN 0231042876.

41. Sallnow, M.J. Communitas Reconsidered: The Sociology of Andean Pilgrimage. Man 1981, 16, $163-182$. [CrossRef]

42. Eade, J.; Sallnow, M.J. Contesting the Sacred: The Anthropology of Pilgrimage; Eade, J., Sallnow, M.J., Eds.; University of Illinois Press: Champaign, IL, USA, 2000; ISBN 0252069404.

43. Cohen, E. Pilgrimage centers: Concentric and excentric. Ann. Tour. Res. 1992, 19, 33-50. [CrossRef]

44. Eade, J. Pilgrimage and tourism at Lourdes, France. Ann. Tour. Res. 1992, 19, 18-32. [CrossRef]

45. Blackwell, R. Motivation for pilgrimage: Using theory to explore motivations. Scr. Instituti Donneriani Abo. 2010, 22, 24-37. [CrossRef]

46. Poria, Y.; Butler, R.; Airey, D. Tourism, Religion and Religiosity: A Holy Mess. Curr. Issues Tour. 2003, 6, 340-363. [CrossRef]

47. Santos, X.M. Pilgrimage and Tourism at Santiago de Compostela. Tour. Recreat. Res. 2002, 27, 41-50. [CrossRef]

48. Lopez-Guzman, T.; Pérez Gálvez, J.C.; Muñoz-Fernández, G.A.; Medina-Viruel, M.J. Cultural identity in WHS tourist destinations: The case of Cordoba (Spain). Int. J. Cult. Tour. Hosp. Res. 2018, 12, 427-439. [CrossRef]

49. Pilgrim's Office Statistics. Available online: https://oficinadelperegrino.com/en/statistics/ (accessed on 5 June 2019).

50. Castro Fernańdez, B.M.; Lois González, R.C.; Lopez, L. Historic city, tourism performance and development: The balance of social behaviours in the city of Santiago de Compostela (Spain). Tour. Hosp. Res. 2016, 16, $282-293$. [CrossRef]

51. Nilsson, M.; Tesfahuney, M. Performing the "post-secular" in Santiago de Compostela. Ann. Tour. Res. 2016, 57, 18-30. [CrossRef]

52. Woodside, A.G.; Martin, D. Introduction: The tourist gaze 4.0: Uncovering non-conscious meanings and motivations in the stories tourists tell of trip and destination experiences. Int. J. Tour. Anthropol. 2015, 4, 1-12. [CrossRef]

53. Uriely, N. The tourist experience: Conceptual Developments. Ann. Tour. Res. 2005, 32, 199-216. [CrossRef]

54. MacCannell, D. Tourist agency. Tour. Stud. 2001, 1, 23-37. [CrossRef]

55. Perkins, H.C.; Thorns, D.C. Gazing or Performing? Int. Sociol. 2001, 16, 185-204. [CrossRef]

56. Larsen, S. Aspects of a Psychology of the Tourist Experience. Scand. J. Hosp. Tour. 2007, 7, 7-18. [CrossRef]

57. Wertheimer, M.; Riezler, K. Gestalt Theory (With a Foreword by Kurt Riezler)—ProQuest. Soc. Res. (New York) 1977, 11, 78-99.

58. Smith, V.L. Introduction: The quest in guest. Ann. Tour. Res. 1992, 19, 1-17. [CrossRef]

59. Crompton, J.L. An Assessment of the Image of Mexico as a Vacation Destination and the Influence of Geographical Location Upon That Image. J. Travel Res. 1979, 17, 18-23. [CrossRef]

60. Dann, G.M.S. Anomie, ego-enhancement and tourism. Ann. Tour. Res. 1977, 4, 184-194. [CrossRef]

61. Collins-Kreiner, N.; Kliot, N. Pilgrimage tourism in the Holy Land: The behavioural characteristics of Christian pilgrims. GeoJournal 2000, 50, 55-67. [CrossRef]

62. Collins-Kreiner, N. Researching pilgrimage. Ann. Tour. Res. 2010, 37, 440-456. [CrossRef]

63. Barber, R.W. Pilgrimages; Boydell Press: London, UK, 1993; ISBN 0851154719.

64. Coleman, S.; Eade, J. Introduction: Reframing pilgrimage. In Reframing Pilgrimage: Cultures in Motion; Coleman, S., Eade, J., Eds.; Routledge: London, UK, 2004; pp. 1-25. ISBN 0415303540.

65. Turner, V. The Center out There: Pilgrim's Goal. Hist. Relig. 1973, 12, 191-230. [CrossRef]

66. Digance, J. Pilgrimage at contested sites. Ann. Tour. Res. 2003, 30, 143-159. [CrossRef]

67. Shinde, K.A. Entrepreneurship and indigenous enterpreneurs in religious tourism in India. Int. J. Tour. Res. 2010, 12, 523-535. [CrossRef] 
68. Timothy, D.J.; Olsen, D.H. Tourism, Religion and Spiritual Journeys; Routledge: Abingdon, UK, 2006; ISBN 1134257570.

69. Coleman, S. From England's Nazareth to Sweden's Jerusalem: Movement, (virtual) landscapes and pilgrimage. In Reframing Pilgrimage: Cultures in Motion; Coleman, S., Eade, J., Eds.; Routledge: London, UK, 2006; pp. $45-46$.

70. MacCannell, D. Staged Authenticity: Arrangements of Social Space in Tourist Settings. Am. J. Sociol. 1973, 79, 589-603. [CrossRef]

71. MacCannell, D. The Tourist: A New Theory of the Leisure Class; Schocken Books: New York, NY, USA, 1989; ISBN 0520280008.

72. Cohen, E. A Phenomenology of Tourist Experiences. Sociology 1979, 13, 179-201. [CrossRef]

73. Nolan, M.L.; Nolan, S. Christian Pilgrimage in Modern Western Europe; University of North Carolina Press: Chapel Hill, NC, USA, 1989; ISBN 0807818143.

74. Archicompostela. Peregrinos en Los Últimos Años. Available online: https://web.archive.org/web/ 20100101094841/http:/www.archicompostela.org/peregrinos/Estadisticas/peregrinanos.htm (accessed on 15 June 2019).

75. Council of Europe Santiago de Compostela Pilgrim Routes. Available online: https://www.coe.int/en/web/ cultural-routes/the-santiago-de-compostela-pilgrim-routes (accessed on 15 June 2019).

76. UNESCO. Religious Destination: Santiago de Compostela; UNESCO: Paris, France, 2010.

77. Sharpley, R.; Sundaram, P. Tourism: A sacred journey? The case of ashram tourism, India. Int. J. Tour. Res. 2005, 7, 161-171. [CrossRef]

78. Pérez Guilarte, Y.; Lois González, R.C. Sustainability and visitor management in tourist historic cities: The case of Santiago de Compostela, Spain. J. Herit. Tour. 2018, 13, 489-505. [CrossRef]

79. Antunes, A.; Amaro, S.; Henriques, C. Motivations for Pilgrimage: Why pilgrims travel El Camiño de Santiago. In Proceedings of the International Religious Tourism and Pilgrimage Conference, Armeno, Italy, 28 June-1 July 2017.

80. Blom, T.; Nilsson, M.; Santos, X. The way to Santiago beyond Santiago. Fisterra and the pilgrimage's post-secular meaning. Eur. J. Tour. Res. 2016, 12, 113-146.

81. Preston, C.C.; Colman, A.M. Optimal number of response categories in rating scales: Reliability, validity, discriminating power, and respondent preferences. Acta Psychol. (Amst.) 2000, 104, 1-15. [CrossRef]

82. Tapachai, N.; Waryszak, R. An Examination of the Role of Beneficial Image in Tourist Destination Selection. J. Travel Res. 2000, 39, 37-44. [CrossRef]

83. McDougall, G.H.G.; Fry, J.N. Combining two methods of image measurement. J. Retail. 1974, 50, 53-61.

84. Hudson, S. Consumer behavior in travel and tourism. In Consumer Behavior in Travel and Tourism; Pizam, A., Mansfeld, Y., Eds.; Haworth Hospitality Press: New York, NY, USA, 1999; p. 530. ISBN 0789006103.

85. Baloglu, S.; Uysal, M. Market segments of push and pull motivations: A canonical correlation approach. Int. J. Contemp. Hosp. Manag. 1996, 8, 32-38. [CrossRef]

86. Iso-Ahola, S.E. Toward a social psychological theory of tourism motivation: A rejoinder. Ann. Tour. Res. 1982, 9, 256-262. [CrossRef]

87. Pearce, P. Fundamentals of tourist motivation. In Tourism Research: Critiques and Challenges; Pearce, D.G., Butler, R.W., Eds.; Routledge: London, UK, 1993; pp. 113-134.

88. Ryan, C. Motives, behaviours, body and mind. In The Tourist Experience; Ryan, C., Ed.; Continuum: London, UK, 2002; pp. 27-57. ISBN 0826457649.

89. Mansfeld, Y. From motivation to actual travel. Ann. Tour. Res. 1992, 19, 399-419. [CrossRef]

90. Baloglu, S. A Path Analytic Model of Visitation Intention Involving Information Sources, Socio-Psychological Motivations, and Destination Image. J. Travel Tour. Mark. 2000, 8, 81-90. [CrossRef]

91. Ryan, C.; Glendon, I. Application of leisure motivation scale to tourism. Ann. Tour. Res. 1998, 25, 169-184. [CrossRef]

92. Youcheng, W.; Fesenmaier, D.R. Assessing Motivation of Contribution in Online Communities: An Empirical Investigation of an Online Travel Community. Electron. Mark. 2003, 13, 33-45. [CrossRef]

93. Post, P.; Pieper, J.; van Uden, M. The Modern Pilgrim: Multidisciplinary Explorations of Christian Pilgrimage; Peters Publishers: Leuven, Belgium, 1998.

94. Yoon, Y.; Uysal, M. An examination of the effects of motivation and satisfaction on destination loyalty: A structural model. Tour. Manag. 2005, 26, 45-56. [CrossRef] 
95. Baloglu, S.; McCleary, K.W. U.S. International Pleasure Travelers' Images of Four Mediterranean Destinations: A Comparison of Visitors and Nonvisitors. J. Travel Res. 1999, 38, 144-152. [CrossRef]

96. Klenosky, D.B. The "Pull" of Tourism Destinations: A Means-End Investigation. J. Travel Res. 2002, 40, $396-403$. [CrossRef]

97. Chul Oh, H.; Uysal, M.; Weaver, P.A. Product bundles and market segments based on travel motivations: A canonical correlation approach. Int. J. Hosp. Manag. 1995, 14, 123-137. [CrossRef]

98. Dann, G.M.S. Tourist motivation an appraisal. Ann. Tour. Res. 1981, 8, 187-219. [CrossRef]

99. Sato, S.; Kim, H.; Buning, R.J.; Harada, M. Adventure tourism motivation and destination loyalty: A comparison of decision and non-decision makers. J. Destin. Mark. Manag. 2016. [CrossRef]

100. Cha, S.; Mccleary, K.W.; Uysal, M. Travel Motivations of Japanese Overseas Travelers: A Factor-Cluster Segmentation Approach. J. Travel Res. 1995, 34, 33-39. [CrossRef]

101. Aronson, J. A Pragmatic View of Thematic Analysis. Qual. Rep. 1995, 2, 1-3.

102. Boyatzis, R.E. Transforming Qualitative Information: Thematic Analysis and Code Development; Sage Publications: Thousand Oaks, CA, USA, 1998; ISBN 0761909613.

103. Braun, V.; Clarke, V. Using thematic analysis in psychology. Qual. Res. Psychol. 2006, 3, 77-101. [CrossRef]

104. Patton, M.Q. Qualitative Research E Evaluation Methods; Beverly Hills: Thousand Oaks, CA, USA, 1980.

105. Nunkoo, R.; Ramkissoon, H. Stakeholders' views of enclave tourism. J. Hosp. Tour. Res. 2016, 40, 557-558. [CrossRef]

106. Junek, O.; Killion, L. Grounded Theory. In Handbook of Research Methods in Tourism: Quantitative and Qualitative Approaches; Dwyer, L., Gill, A., Seetaram, N., Eds.; Edward Elgar: Cheltenhan, UK, 2012; pp. 325-339. ISBN 9781781001295.

107. Banyai, M.; Glover, T.D. Evaluating Research Methods on Travel Blogs. J. Travel Res. 2012, 51, $267-277$. [CrossRef]

108. Kim, H.; Stepchenkova, S. Understanding destination personality through visitors' experience: A cross-cultural perspective. J. Destin. Mark. Manag. 2017, 6, 416-425. [CrossRef]

109. TripAdvisor. TripAdvisor Network Effect and the Benefits of Total Engagement. TripAdvisor Insights. Available online: https://www.tripadvisor.com/TripAdvisorInsights/w828 (accessed on 16 June 2019).

110. Banerjee, S.; Chua, A.Y.K. In search of patterns among travellers' hotel ratings in TripAdvisor. Tour. Manag. 2016, 53, 125-131. [CrossRef]

111. Yoo, K.H.; Gretzel, U. What Motivates Consumers to Write Online Travel Reviews? Inf. Technol. Tour. 2008, 10, 283-295. [CrossRef]

112. Arsal, I.; Backman, S.; Baldwin, E. Influence of an Online Travel Community on Travel Decisions. In Information and Communication Technologies in Tourism 2008; Springer: Vienna, Austria, 2008; pp. 82-93.

113. TripAdviosr Camino de Santiago (Santiago de Compostela)—2019 All You Need to Know BEFORE You Go (with Photos)—TripAdvisor. Available online: https://www.tripadvisor.com/Attraction_Review-g187508d500410-Reviews-Camino_de_Santiago-Santiago_de_Compostela_Province_of_A_Coruna_Galicia.html (accessed on 15 November 2014).

114. Camino Forum Camino de Santiago Forum. Available online: https://www.caminodesantiago.me/ community/ (accessed on 15 December 2014).

115. Belhassen, Y.; Caton, K.; Stewart, W.P. The search for authenticity in the pilgrim experience. Ann. Tour. Res. 2008, 35, 668-689. [CrossRef]

(C) 2019 by the authors. Licensee MDPI, Basel, Switzerland. This article is an open access article distributed under the terms and conditions of the Creative Commons Attribution (CC BY) license (http://creativecommons.org/licenses/by/4.0/). 